\title{
DOES THE POLICY OF RURAL LAND RIGHTS CONFIRMATION PROMOTE THE TRANSFER OF FARMLAND IN CHINA? *
}

\author{
Hengzhou XU - Yihang ZHAO - Ronghui TAN - Hongchun YIN
}

(Received: 12 January 2017; revision received: 27 March 2017;

accepted: 16 May 2017)

Land tenure security and land transfer markets are once again a topmost priority in the policy development agenda because of their expected outcomes in terms of equity and efficiency in the rural sector of China. The policy of rural land rights confirmation has been implemented since 2010 to enhance land tenure security and the transferability of farmland. However, only a few studies have been conducted on the effect of rural land rights confirmation on farmland transfer. Therefore, we use household-level survey data from 48 villages across Tianjin City and Shandong Province to explore whether rural land rights confirmation promotes the transfer of farmlands. Our empirical results show that rural land rights confirmation has significant and positive effects on the likelihood and amount of transfer-out land at the 5\% significance level, but the effect on transfer-in farmland is insignificant. The results of the study have several policy implications. For instance, the agricultural comparative advantage should be improved through various agricultural subsidy policies. Moreover, the intermediary service network for farmland transfer should be established, and strengthening the non-farm employment skills and improving the non-agricultural employment market are necessary for the rural labour force.

Keywords: rural land rights confirmation, farmland transfer, land tenure security, China

\section{JEL classification indices: Q15}

* The authors gratefully acknowledge the financial support from the National Social Science Foundation of China (Grants: 17BJY090).

Hengzhou $X u$, Associate Professor, School of Management and Economics, Tianjin University, Tianjin, P.R. China. E-mail: xuhengzhou@163.com

Yihang Zhao, Master, School of Management and Economics, Tianjin University, Tianjin, P.R. China. E-mail: yihangzhao@tju.edu.cn

Ronghui Tan, corresponding author. Assistant Professor, School of Management and Economics, Tianjin University, Tianjin, P.R. China. E-mail: tjtrh@126.com

Hongchun Yin, Associate Professor, School of Management and Economics, Tianjin University, Tianjin, P.R. China. E-mail: tjuachun@163.com 


\section{INTRODUCTION}

Economic reforms initiated in the late 1970s drastically affected the development of the Chinese agricultural sector. In particular, the switch from collective farming to the household responsibility system (HRS) has resulted in an important change in the land tenure system. The implementation of this new land tenure system led to the rapid growth of agricultural productivity in the early reform years (1979-1984), which linked the income of farm households closely to their own performance (Fan 1991; Lin 1992). However, the high level of farmland fragmentation significantly complicates farming activities. Especially in recent years, farmlands have been broken into small land-ownership parcels, and they have lost their attractiveness for farming, particularly for the farmers themselves. The plots are unprofitable for owner-cultivation because of the small, often scattered, and inconveniently shaped parcels that lead to higher expenditure and lower farm productivity (del Corral et al. 2011; Latruffe - Piet 2012). To solve these problems, the Chinese government permitted land rentals in the mid-1980s. In 1993, the government allowed the extension of land use rights for another 30 years. Since then, a rural land rental market has emerged.

According to the statistics of the Ministry of Agriculture, the proportion of rural land transfer reached no more than $26 \%$ by the end of 2013 . The low incidence of land rental transactions can be explained by the type of land tenure and other related institutions in China. First, land in rural China is owned commonly, and access to its use is guaranteed either by birth or is acquired through marriage; thus, the scope of land rental activity is inevitably reduced (Turner et al. 2001). In addition, the frequent administrative reallocations of land by the village collective, used to take into account demographic changes, demonstrated their shortcomings in adjusting social relations during and after land acquisition because of the problematic land revenue redistribution and forced land acquisitions. All of the above factors have resulted in insecure land use rights and in the decrease in incentives for farm households to engage in long-term land investment (Feng 2008). Combined, these institutional features have a constraining effect on the development of the land rental market.

To respond to this problem, the government has implemented a series of legal land tenure reforms that aim to improve the legal tenure security and transferability of farmland since 1998 (Ma et al. 2015). The government therefore provided more detailed stipulations in the Rural Land Contract Law (RLCL) of 2002 and the Property Law (PL) of 2007. In 2010, the authorities issued their first policy document (Central Document No. 1) with the aim of deepening the reform of the rural land system. In this document, they guaranteed that farmers would be granted more property rights, e.g. by accelerating the rural land rights confirmation, 
and that rural land contract relations would remain unchanged in the long term. At the same time, the local governments are obliged to register and certify rural land-use rights. In addition, they are required to make the transfer of contracted land-use rights to ensure that the transformation policy can be implemented correctly and in an orderly fashion. In 2013 and 2014, the central government even emphasised the acceleration of the afore-mentioned work. In other words, the government seeks to promote the transfer of farmland by strengthening the policy of rural land rights confirmation (i.e. registration, titling, and certification of rural land rights). However, the real effect of the policy is still unknown, and few studies have focused on this issue.

Secure and easily transferable rights to land have long been identified as a key element in bringing high levels of investment and easy access to credit, in facilitating the reallocation of production factors to maximise allocative efficiency in resource use, and in enabling economic diversification and growth (Deininger - Jin 2006). In many instances, tenure security correlates with participation in the land rental market (Gebreselassie 2006; Ghebru - Holden 2008). In fact, empirical analysis suggests that insecure rights can reduce the level of activity in land rental markets and simultaneously induce market segmentation by limiting transactions to a close circle of relatives in which social sanctions can be applied to ensure the recovery of land (Deininger - Jin 2005; Wang et al. 2015).

Land registration and titling programmes have been implemented in many countries to grant land rights to farmers. In many parts of the world, these land registration and titling programmes have led to enhanced tenure security and increased economic gains. In the Dominican Republic, for example, simulations suggested that increasing security of tenure could increase the total area rented by the poor by $63 \%$ and that this would increase security dramatically affecting the lives of the poor (Macours et al. 2004). Similarly, in Nicaragua, producers who had titles were significantly more likely to rent out their land, thus providing an opportunity for more effective producers to increase their cultivated areas (Deininger et al. 2003). Furthermore, additional findings indicate that rural land security conditions produce desirable social outcomes, such as the performance of local institutions (Deininger et al. 2003; Deininger - Jin 2006) and even of the state (Banerjee - Iyer 2005).

In Africa, land registration and titling programmes have been implemented since World War II to improve tenure security. However, these land registration and titling initiatives had relatively disappointing results. The failure of these programmes to enhance tenure security is largely attributed to their unsuccessful design and implementation (e.g. Deininger et al. 2003; Crewett - Korf 2008). Crewett - Korf (2008) argued that the structure of the existing land tenure systems in Ethiopia is largely characterised by top-down approaches that do not consider 
specific local needs. The failure of titling programmes in Africa is well documented. In most cases, these programmes ignored the premise that they had been proven effective (e.g. Peters 2004; Shipton 2009). In particular, many programmes were implemented without examining whether the landholders who were supposed to benefit from the titling programmes considered the titles or deeds useful and whether they were likely to register transactions after the first registration.

A large number of studies have suggested that renting out land may be considered a signal to take land away from them because of insecure land rights (Yang 1997; Holden - Yohannes 2002), or that tenants may not give the land back upon the expiry of the lease contract. Furthermore, the level of participation in land markets may be sub-optimal. Tenure insecurity of rural land under the HRS in China is stimulated by the risk of land expropriation for urban expansion and infrastructure development (Tao - Xu 2007). In addition to tenure insecurity, land transfer markets continue to be thin. Land transfers that do not violate the contract that farmers signed with the village collective are technically permitted and informed by the village leader. Although land rentals increased after the tenure reforms in 2002, Deininger - Jin (2009) found that contracts remained informal and unwritten, and that these contracts were frequently made with relatives.

As shown above, land registration and titling programmes have been implemented continuously in developing countries all over the world. However, to our knowledge, only a few studies have provided empirical estimates on the extent of the influence of rural land rights confirmation on farmland transfer in China. The objective of this study is to estimate the effect of rural land rights confirmation on farmland transfer in rural China. Particularly, we test whether households will transfer in/out more land if they are given the rural land contract management certificate (RLCMC).

This study is structured as follows. Section 2 describes the history of land reform in rural China and reviews the rural land rights confirmation programme. Section 3 presents the data and the method used. Section 4 discusses the econometric results of the regression model. Section 5 concludes the study by putting the results into context and drawing policy implications.

\section{RURAL LAND REFORM AND LAND RIGHTS CONFIRMATION}

Land policies and interventions that directly or indirectly affect the security of property rights to rural land have been a key issue throughout China's history. Before the communist revolution, most Chinese farmers were poor tenants or owners of small plots. After the communist government took over, it confiscated the large holdings of property owners and distributed land rights to households 
on an egalitarian basis (Prosterman et al. 1990). In the 1950s, a policy of collectivisation that required farmers to surrender lands to collectives was adopted and resulted in disastrous consequences of output and rural welfare, in which millions of rural dwellers perished from 1958 to 1960 (Putterman - Skillman 1993; Yao 1999; Lin - Yang 2000).

To solve these problems and improve productivity, the HRS was introduced in the late 1970s, while the communes were dissolved in 1984. The HRS aims to extend land-use rights and authorise individual households with income rights. Under the HRS, rural land ownerships belong to a village collective, and land use rights are allocated among village households. Rural households have held individual rights to use the land since the 1980s, although these rights are incomplete. Liu et al. (1998) reviewed four aspects of land rights that could vary among Chinese villages: residual income rights, unencumbered use rights, rights to secure possession, and transfer rights. As a result of the gradual strengthening of overall property rights since the 1980 s, residual income rights and unencumbered use rights are now universal.

In contrast to the situation of income rights and use rights, households in many areas in China have been reported to have poor land tenure security rights. Land tenure security under the HRS is determined primarily by two factors. The first is the duration of the lease of land to a household. In the early stages of the HRS, land contract period was only one year or two years. However, officials realised that such a short contract period offered households poor land tenure security and discouraged them from making land-improving investments. Therefore, land contract terms under the HRS were extended to 15 years or more (Putterman 1993; Zhang - Makeham1992).

The second factor influencing land tenure security under the HRS is the periodic reallocation of land by village authorities. Lengthening contract periods did not always improve the tenure security of rural households as village leaders in many Chinese villages reallocated some or even all of the land using their administrative power. The allocation of land based on egalitarian principles serves to grant all households in a village collective equal access to vital (equitable) land resources that are needed to provide a livelihood. These reassignments often occurred despite the existence of long-term use right contracts. Studies have shown that two-thirds of Chinese villages reallocated land through administrative methods, and that this often occurred in the middle of land contract times (He 1995; Brandt et al. 2005). Therefore, the existence of long-term land contracts is usually an insufficient condition to ensure tenure security for agricultural households because of administrative reallocations within the period of the HRS contracts. In 1984, the government adopted Rural Work Document No. 1, which states that land assignments under the HRS should last for at least 15 years. Thus, 
village leaders should not reassign lands during the contract period. However, based on egalitarian principles that serve to grant all households in a village collective equal access to vital (equitable) land resources that are needed to provide a livelihood, rural land must be reassigned. Furthermore, the document encouraged farmers to transfer land use rights through decentralised land markets and discouraged the use of administrative land reallocations (Cheng - Tsang 1995). The first Land Administration Law (LAL) was adopted in 1986, and it formally introduced the basis of the HRS. Under the LAL, the rights of farmers to lands were supposedly secure and extended. However, the original aim of LAL was not achieved because of the short lease period and the periodic reallocations of land by village authorities (Krusekopf 2002).

In 1994, the Chinese Communist Party's Central Committee adopted a resolution calling for land use contracts to be extended for 30 years when the original 15 -year contracts expired, and this resolution was supported by the law through the revision of LAL in 1998. The stipulations in the LAL revision state that land certificates should be issued to protect land use rights, that acceptance by twothirds of representatives of villagers and approval of higher-level governments are needed for land reallocation within villages, and that land transfers to individuals and units outside the village are obtained with the approval of two-thirds of the congress or delegates of villagers (Ho 2001).

In order to strengthen further the rights of farmers to rural land, the Rural Land Contracting Law (RLCL) was adopted by the Party's Standing Committee in August 2002 and was made effective in March 2003. The RLCL insists that these contracts be written and include, in addition to the names of the parties involved, specific details on location, area, quality, and use of the contracted land, the rights and obligations of both parties, the contract term, and the liabilities in case of contract violation. To prevent the alteration of contract terms or the unilateral "cancellation" by village leaders if there is need for land (e.g. for industrial projects), contracts are supposed to be registered by the county or provincial government that maintains copies that can be called upon in case of loss of the original contract or in cases of dispute. The RLCL enables land use rights to be exchanged and to be leased, transferred, and assigned to others to a greater extent than was possible before. In the case of transfers that leave the original contracting relationship unchanged, the collective has to be notified, but no approval is needed. Transactions with a duration longer than one year require a written agreement and can be registered by the village on a voluntary basis. In the case of reassignment that terminates the original contracting relationship, approval by the collective landowner is required.

The Property Law (PL) of 2007 further increased legal land tenure security in rural (and urban) areas. Land reallocations within villages are now allowed only 
in case of a natural disaster or other special circumstances specified by the RLCL of 2002. PL implicitly grants farmers perpetual rights, and it states that farmers should retain and inherit their rights according to relevant rules when the 30-year period has passed. Further legal support of the interests of farmers is provided by the Mediation and Arbitration of Rural Land Contract Disputes Law, which was adopted in 2009, and this law sets out principles related to the use of mediation or arbitration to settle land disputes (Ma et al. 2015).

In Central Document No. 1 of 2010, the central state decreed in unusually powerful wording that titles be issued to "all rural collective economic organisations with ownership rights within 3 years". Toward the deadline, Document No. 1 of 2013 stipulated that the registration and certification for rural land contract management rights should be completed within five years, and further implementation of this work was mentioned in the Document No. 1 of 2014 of the central government.

\section{A CONCEPTUAL FRAMEWORK}

It would be useful to start with a conceptual framework for the relationship between rural land rights confirmation and the transfer of farmland. Such a framework was first developed in the context of a study on rural Thailand (Yongyuth et al. 1988). In his conceptual model linking land titles and productivity in Thai agriculture, Yongyuth hypothesised that there are at least three important economic relationships to consider: (1) that title can be used as collateral to improve access to credit for agricultural investment, (2) that title could increase security of tenure for farmers and enhance their willingness to make medium-term to longterm investments on their land, and (3) that title may stimulate land markets that will facilitate the transfer of land resources to the more productive farmers. In Thailand, different institutions provide different types of land documents reflecting different levels of tenure security. Three levels of land tenure security, namely secure, temporary and insecure, were classified from different types of land titles or certificates as follows: (1) Secure land tenure refers to the possession of private land with land titles issued by the Department of Lands, including title deed. The landowners who hold this certificate possess unrestricted rights of sale, transfer, and inheritance. (2) Temporary land tenure refers to the possession of land with other forms of land documents issued by respective departments. (3) Insecure land tenure refers to the possession of land without recognised documents or with only tax payment. These pathways have subsequently been used by economists to test for linkages between tenure security, investment, and productivity as well as the impact of land markets and other policy instruments. 
We assumed that farmers have more secure land rights by the policy of rural land rights confirmation. Moreover, higher tenure security was seen as critical for more active rental markets and a vibrant off-farm economy in China (Jin - Deininger 2009). This conceptual framework of rural land rights confirmation-farmland transfer is presented in Figure 1. Different type of farmers, such as farmers good at farming and farmers who have worked in the non-agricultural sector, can all benefit from the policy of rural land rights confirmation. On the one hand, land rights confirmation enhanced the land tenure security; the majority of farmers in our survey samples in China believed that land rights confirmation reduced the likelihood of a land dispute. More secure land rights and the presence of land rights confirmation are often associated with an increased likelihood of making certain types of investment, for example, tree planting, fencing, and manuring, and it also raised the participation of farmers in land rental markets. Deininger Jin (2006) found that more private transfer rights have a strong positive effect on investment and terracing in countrywide sample in Ethiopia. On the other hand, before the implementation of rural land rights confirmation, farmers who worked off-farm were afraid of renting out their rural land because doing so could be perceived as a signal that the land was no longer needed and could be administratively reallocated to other households. With the implementation of rural land rights confirmation, formal property rights may serve as collateral, thereby allowing a household to access credit markets, which is very important for farmers who worked off-farm.

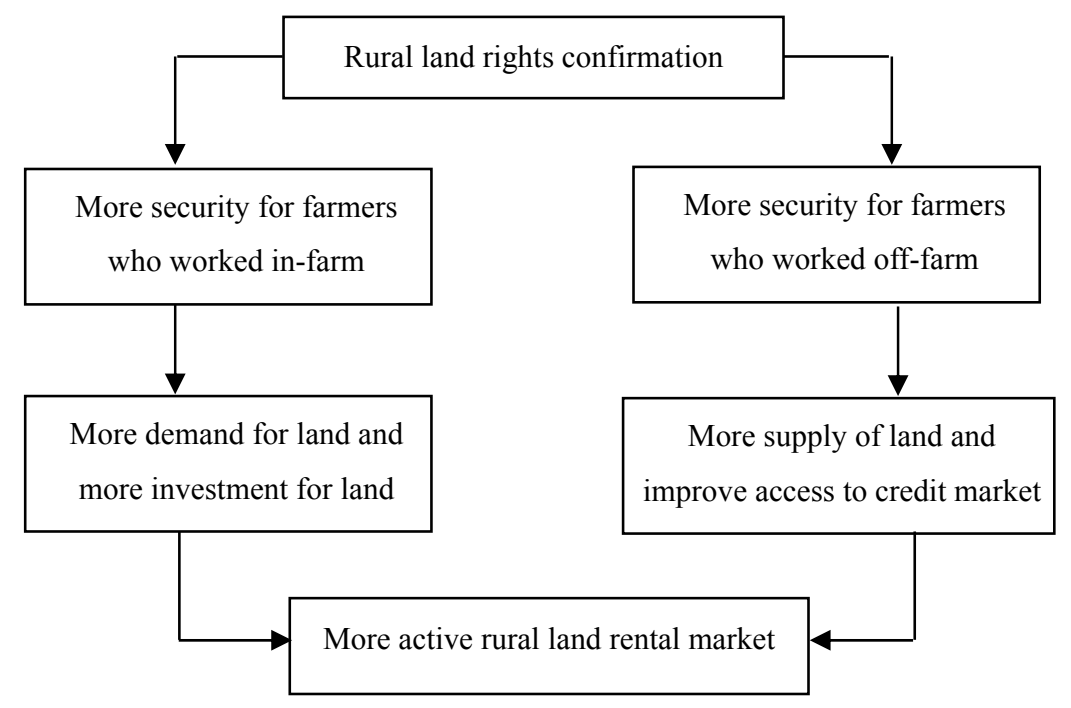

Figure 1. Rural land rights confirmation and farmland transfer: a conceptual framework 


\section{METHODOLOGY AND DATA}

\section{Model specification and variables}

We estimate the following OLS econometric model and empirically test whether the policy of rural land rights confirmation promotes the transfer of farmland in rural China by applying the household survey data. The structure of our econometric model is

$$
\mathrm{Y}_{\mathrm{i}}=\mathrm{c}+\alpha_{\mathrm{i}} \mathrm{LC}_{\mathrm{i}}+\beta_{\mathrm{i}} \mathrm{X}_{\mathrm{i}}+\mu_{\mathrm{i} .} .
$$

Formula (1) is the basic model reflecting the effect of rural land rights confirmation on farmland transfer.

The dependent variable $Y_{i}$ is the transfer rate of farmland for the household (including transfer in and transfer out) (unit: \%). The household that transfers in or out farmland at least once in 2010-2014 is defined as the transfer-in or transferout household, respectively. If the farmland transfer of a household did not occur in 2010-2014, the household is excluded from the sample household. According to the research purpose, the transfer rate of farmland for household is divided into the transfer rate of farmland for transfer-in household and transfer-out household. The transfer rate of farmland for transfer-in household = the transfer-in farmland area / (farmland area owned by the transfer-in household at the beginning of the year + the transfer-in farmland area). The transfer rate of farmland for transferout household = the transfer-out farmland area/farmland area owned by the transfer-out household at the beginning of the year. Theoretically, a household may transfer out farmland first in a particular year and then transfer in farmland in subsequent years. However, this kind of household does not exist in our sample.

The variable $L C_{i}$ represents the indicator of land rights confirmation that reflects households that can hold RLCMC or those households that cannot. The group of variables $X_{i}$ denotes the other control variables except $L C_{i} . \alpha_{i}$ and $\beta_{i}$ are the coefficients of the variables $L C_{i}$ and $X_{i}$, respectively. $c$ is the constant, and $\mu_{i}$ is the error item.

We select 8 control variables by referring to existing research (Deininger - Jin 2005; Feng et al. 2010; Mullan et al. 2011; Sitko et al. 2014). These control variables are the individual and household characteristic variables, such as sex of the household head ( $\mathrm{SH})$, age of the household head ( $\mathrm{AH})$, education of the household head (EH), per capita farmland endowment (PCFE), ratio of agricultural income in family (RAIF), ratio of off-farm labour in family (ROLF), number of dependents (NP), and dummy variable. The detailed information of control variables is as follows. 
As for the households which rent in land, with the growth of age of the household heads and the increase of agricultural experience, they may be inclined to rent in rural land, but when reaching a certain age, with the decline of physical fitness and energy, they may prefer to rent in less rural land. Taking the age of sample household heads into account, they are generally older, the average age is 49.36 years (Table 1), thus the impact of age of rent-in household heads on farmland transfer in is expected to be negative. As for the households which rent out land, with the increase of the age of the household heads and the increase of non-agricultural experience, they may be inclined to rent out rural land, but when a certain age is reached, with the decline of physical fitness and energy, the income and opportunity of engaging in non-agricultural employment may be reduced, and they may not prefer to rent out rural land. Therefore, the impact of age of rent-out household heads on farmland transfer is expected to be uncertain. The impact of sex and education level of household heads on farmland transfer is also expected to be uncertain. Male and well-educated household heads may have more opportunities to engage in non-agricultural employment, and thus tend

Table 1.Descriptive statistics of the variables

\begin{tabular}{|c|c|c|c|c|c|}
\hline \multirow{2}{*}{ Variable } & \multirow{2}{*}{ Definition } & \multicolumn{2}{|c|}{$\begin{array}{l}\text { Land transfer-in } \\
\text { household }\end{array}$} & \multicolumn{2}{|c|}{$\begin{array}{l}\text { Land transfer-out } \\
\text { household }\end{array}$} \\
\hline & & Mean & Stan.dev. & Mean & Stan.dev. \\
\hline \multicolumn{6}{|c|}{ Dependent variables } \\
\hline \multirow{2}{*}{$\begin{array}{l}\text { Transfer rate } \\
\text { of farmland }\end{array}$} & $\begin{array}{l}\text { Transfer rate of farmland for house- } \\
\text { holds that transfer in farmland }\end{array}$ & 0.58 & 0.24 & & \\
\hline & $\begin{array}{l}\text { Transfer rate of farmland for house- } \\
\text { holds that transfer out farmland }\end{array}$ & & & 0.67 & 0.32 \\
\hline \multicolumn{6}{|c|}{ Independent variables } \\
\hline $\mathrm{SH}$ & $\begin{array}{l}\text { Sex of household head (male }=1 \text {, } \\
\text { female }=0 \text { ) }\end{array}$ & 0.726 & 0.482 & 0.793 & 0.514 \\
\hline $\mathrm{AH}$ & Age of household head & 49.36 & 12.67 & 46.72 & 11.43 \\
\hline $\mathrm{EH}$ & Education level of household head & 6.24 & 2.58 & 6.57 & 2.89 \\
\hline LC & $\begin{array}{l}\text { Whether to hold the RLCMC or not } \\
(1=\text { yes, } 0=\text { no })\end{array}$ & 0.67 & 0.62 & 0.73 & 0.57 \\
\hline PCFE & Per capita farmland endowment $(\mathrm{mu})$ & 1.26 & 0.57 & 1.18 & 0.46 \\
\hline RAIF & $\begin{array}{l}\text { Ratio of agricultural income in } \\
\text { family }\end{array}$ & 0.73 & 0.49 & 0.34 & 0.17 \\
\hline ROLF & Ratio of off-farm labour in family & 0.27 & 0.30 & 0.53 & 0.38 \\
\hline NP & Number of dependents in family & 2.04 & 1.32 & 1.98 & 1.06 \\
\hline $\begin{array}{l}\text { Provincial } \\
\text { dummy }\end{array}$ & $\begin{array}{l}1=\text { Tianjin City; } 0=\text { Shandong } \\
\text { Province }\end{array}$ & 0.51 & 0.26 & 0.52 & 0.19 \\
\hline
\end{tabular}

Notes: 1 hectare $=15 \mathrm{mu}$.

Source: Authors' calculation based on household survey data. 
to rent out rural land, but at the same time, they may be more likely to accept the new agricultural technology, and thus rent in rural land.

Household characteristic variables include per capita farmland endowment, ratio of agricultural income in family, ratio of off-farm labour in family, and number of dependents. As for the households with adequate owned farmland, this means that the gap from the optimal operation scale of agricultural land is smaller. These kinds of households are more likely to rent in rural land, and vice versa. The higher the ratio of off-farm labour in a family, the more farmers tend to rent out rural land because the family income is mainly dependent on the source of non-farm income. Households with a higher ratio of agricultural income in the family may be inclined to rent in rural land. As for the number of dependents, due to the number of the non-labour force, the impact of the number of dependents on farmland transfer is expected to be uncertain.

The dummy variables for Tianjin City (the sample areas of which are Xiqing and Jinghai) and Shandong Province (the sample areas of which are Linqing and Guanxian) are included to capture the variation in other factors that systematically differ between the two provinces. The summary statistics for the variables is provided in Table 1 .

\section{Data and descriptive statistics}

We obtained the data from the rural household surveys conducted in Tianjin City and Shandong Province both in East China. We selected two counties from each province, three townships from each county, four villages from each township, and 20 households in 48 villages from each village. Altogether, we interviewed representatives of 960 households that were randomly selected from the list of the households provided by the village committees. The interviews were conducted in the selected villages during the Chinese Spring Festival in 2015 as part of our programme supported by the National Natural Science Foundation of China. ${ }^{1}$

The questionnaire included sections on basic households and individual characteristics and information about the rural land rights certificates. Several sections of the household survey were designed to collect information about farmland transfer and rural land rights confirmation. All of the households were asked

A common problem in the rural household surveys is the absence of migrant household members who formally belong to the household according to their rural hukou status. At the same time, they are difficult to interview directly because they work away from home. This problem was minimised in this study as all interviews were conducted during the Spring Festival period. 
Table 2. Distribution of sampled households

\begin{tabular}{l|lcccccc}
\hline \multirow{2}{*}{ Province } & \multirow{3}{*}{ County } & \multicolumn{2}{c}{$\begin{array}{c}\text { Land transfer-in } \\
\text { household }\end{array}$} & \multicolumn{2}{c}{$\begin{array}{c}\text { Land transfer-out } \\
\text { household }\end{array}$} & \multicolumn{2}{c}{ Total } \\
\cline { 3 - 8 } & & Number & $\%$ & Number & $\%$ & Number & $\%$ \\
\hline \multirow{2}{*}{ Tianjin City } & Xiqing & 112 & 26.67 & 110 & 25.35 & 222 & 26.00 \\
& Jinghai & 102 & 24.28 & 114 & 26.27 & 216 & 25.29 \\
Shandong & Linqing & 102 & 24.28 & 107 & 24.65 & 209 & 24.47 \\
Province & Guanxian & 104 & 24.77 & 103 & 23.73 & 207 & 24.24 \\
\hline \multicolumn{2}{l}{ Total } & 420 & 100.00 & 434 & 100.00 & 854 & 100.00 \\
\hline
\end{tabular}

Source: Authors' calculation based on household survey data.

whether there were any farmland transfers in the village in the previous five years and were divided into two categories, namely, transfer in and transfer out. Another section of the survey focused on rural land rights confirmation. The households were asked, for instance, if they had rural land certificates/contracts and when they had received these documents. To ensure the high quality of the data collected, we removed observations with incomplete information and/or incomplete interviews. Our study obtained a total of 854 household questionnaires. The distribution of households is provided in Table 2.

\section{RESULTS}

To investigate more thoroughly the effect of rural land rights confirmation on farmland transfer, we used a multivariable linear regression model. The models were estimated using Eviews 5.0. The results of the method of ordinary least squares estimation are presented in Table 3, which shows that four variables have a significant effect on transfer-in land, and six other variables have a significant effect on transfer-out land.

With regard to the effect of rural land rights confirmation on farmland transfer, two conclusions can be drawn.

(1) For the households that transfer in land, rural land rights confirmation has no significant effect on the likelihood and amount of transfer-in land, which is inconsistent with the findings of Feng (2006) and Ma (2013). The empirical results of the two earlier studies indicated that a more perfect land contract would encourage households to produce, manage, and simultaneously reduce the execution cost of the contract of the rural land transfer. Therefore, giving the certificate of rural land contract management to farmers will urge them to increase the likelihood and size of transfer-in land. In our study, the possible reasons for the findings have two aspects. First, as indicated by our field investigation, the 
Table 3. Estimation results of the effect of rural land rights confirmation on farmland transfer

\begin{tabular}{l|cccc}
\hline \multirow{2}{*}{ Variable } & \multicolumn{2}{|c}{ Land transfer-in household } & \multicolumn{2}{c}{ Land transfer-out household } \\
& Coef. & t-statistic & Coef. & t-statistic \\
\hline SH & -0.027 & -1.372 & -0.018 & -1.251 \\
AH & $-0.025^{* *}$ & -3.726 & $0.019^{* *}$ & 3.405 \\
EH & $-0.036^{*}$ & 2.014 & $0.044^{*}$ & 2.273 \\
LC & 0.030 & 1.207 & $0.028^{* *}$ & 2.946 \\
PCFE & $0.021^{* * *}$ & 4.824 & $-0.016^{* *}$ & -3.513 \\
RAIF & 0.004 & 1.355 & $-0.007^{*}$ & -2.109 \\
ROLF & -0.016 & -1.526 & $0.013^{* *}$ & 3.757 \\
NP & $0.022^{* *}$ & 3.811 & -0.026 & -1.390 \\
Provincial dummy & 0.012 & 1.076 & 0.008 & 1.428 \\
Constant & $0.837^{* * *}$ & 4.182 & $0.918^{* * *}$ & 5.633 \\
Log likelihood & \multicolumn{2}{|c}{172.835} & \multicolumn{2}{c}{124.064} \\
Adjusted R-squared & \multicolumn{3}{|c}{420} \\
\hline No. of observations & \multicolumn{3}{c}{434} \\
\hline
\end{tabular}

Notes: * Denotes the $10 \%, * *$ the $5 \%$, and $* * *$ the $1 \%$ significance level, respectively.

comparative advantage of agriculture is relatively low. Thus, if households that demand the transfer in of farmland are still engaged in food agriculture, they will not bear the transaction costs of farmland transfer. Second, the transaction costs of farmland transfers are relatively high. Existing literature has shown this circumstance (Jin - Deininger 2009; Kimura et al. 2011). The costs are mainly from three aspects based on our survey: the search cost (i.e. the cost for the supply and demand sides to search each other's information), the negotiation cost, and the supervision cost for the execution of the farmland transfer contract.

(2) For households that transfer out land, the empirical results indicate that rural land rights confirmation has a significant and positive effect on the likelihood and amount of transfer-out land. That is, more secure land rights are associated with increased farmland transfer out. The plausible explanation for this finding is that the households that transferred out land have entered the non-agricultural sector. Wage income is the main source of their family, and thus they pay more attention to the property income that comes from the farmland assets and do not intend to easily transfer out land. However, the confirmation of rural land rights, as an effective instrument to improve the security of land tenure, can reduce uncertainties in the process of farmland transfer out and enhance the confidence of the household to obtain the property income from the transferred-out land. This conclusion is in accordance with the findings of Deininger et al. (2003) and Holden et al. (2007). Their empirical results showed that the improvement of land tenure security could decrease the transaction cost of farmland transfer, reduce the risk of losing the transfer-out land for households that transfer out land, and 
then encourage them to transfer out more farmland. Furthermore, the findings of Wang et al. (2015) indicated that possession of land right certificates and fewer major land reallocations encouraged households to engage in land renting to nonfamily members and that the effects of land right certificates were stronger in 2008 than in 2000. However, our finding is inconsistent with Lang et al. (2014) whose empirical results showed that secure land tenure could stimulate the enthusiasm of farmers for land investment, strengthen the "property endowment effect" of farmland, and then reduce the amount of transfer-out farmland.

With regard to the other control variables in Table 3, the age of the household head has a negative and significant effect on the transfer rate of farmland for transfer-in households, but it has a positive and significant effect on the transfer rate for transfer-out households. The older the transfer-in households are, the lower the transfer rate of farmland because the vigour and the age of the household head make conducting large-scale farmland management difficult. However, for the transfer-out households, as household heads grow older, their labour abilities gradually weaken. Thus, the family income comes mainly from the children of the household heads, and the likelihood of transferring-out more land is higher for them. This finding is consistent with that of Ma et al. (2015). The coefficient of education of household heads is significant at the $10 \%$ level in the two models, and thus the signs of the two estimated coefficients are opposite. Table 3 shows that the households with a higher level of education are likely to transfer out more land, whereas the opposite is true for the households that transfer in land. One implication is that the opportunity to engage in non-farm activities increases with education, and therefore households transfer out land to substitute their time away from agricultural production. This finding corroborates those of Deininger et al. (2003), Teklu - Lemi (2004), and Swinnen et al. (2006), but refutes those of Tikabo - Holden (2004) and Masterson (2007), who noted that the education of farmers had either a negative effect on land transfer out or a positive effect on land transfer in, implying imperfection in the market for human capital. By contrast, Vranken - Swinnen (2006) noted that education significantly reduced the demand for transfer-in land in Hungary; this finding was also observed in our study.

Among the household characteristic variables, the coefficient of per capita farmland endowment is significant at the $1 \%$ and $5 \%$ level in the two models. However, the sign of the coefficient estimation is opposite, indicating that a cyclic cumulative effect exists on farmland transfer. That is, households rich in initial per capita farmland endowment have a stronger desire to transfer in more farmland, while households with lower initial farmland endowment are likely to transfer out farmland. Several reasons can explain this finding. First, scale management is unfavourable for households with inadequate owned farmland. This 
kind of household has restricted agricultural productivity, but increased costs of agricultural investment. Second, the ratio of agricultural income in a family has significant and negative effects on the transfer-out model, implying that households with a high share of agricultural income are unlikely to transfer out land to others. This finding corroborates the study of Kung (2002), who noted that households with active participation in the off-farm labour market transfer out more land in China. The ratio of off-farm labour in a family has a positive and significant effect on the transfer-out model, whereas, the number of dependents in a family has a positive and significant effect on the transfer-in model.

\section{CONCLUSION}

This study examines the effects of rural land confirmation on the transfer of farmland from the perspective of transfer-in and transfer-out households. Data from rural household surveys conducted in Tianjin City and in the northwest of Shandong Province in 2015. Our findings show that rural land rights confirmation has a significant and positive effect on the likelihood and amount of transfer-out land at the 5\% significance level, but its effect on transfer-in land is insignificant.

Several implications for policy can be drawn from the above. First, in order to strengthen the farmers' expectations of land transfer, the structure and functions of rural land rights should be further improved, and land contract rights and land management rights should be clearly defined. In addition, the policy should aim at developing land contractual management rights mortgage and loan, as this would break the restriction in which the land in rural areas could not be used as collateral.

Second, to improve agricultural comparative advantages, government policy should pay more attention to further increasing the intensity of agricultural subsidies for farmland scale management. The agricultural subsidies should be paid to practical agricultural land managers such as grain growers, and it should be decoupled from the rural land contractual relationship.

Finally, to strengthen non-agricultural employment skills, especially for households that transfer out land, multiple levels of a vocational skills training system for farmers should be established. Through the training system, necessary conditions and effective space for the transfer of farmland can be created. The key principle is to reduce the reliance of farmers on land as a source of social security. Basic social services for households that engage in non-agricultural employment in urban areas should be established and let hukou system return to the function of household registration and statistics. Furthermore, medical insurance and other social insurance systems should be expanded and improved in rural areas. 


\section{REFERENCES}

Banerjee, A. - Iyer, L. (2005): History, Institutions and Economic Performance: The Legacy of Colonial Land Tenure Systems in India. The American Economic Review, 95(4): 1190-1213.

Brandt, L. - Rozelle, S. - Li, G. - Huang, J. (2005): Land Tenure in China: Facts, Fictions and Issues. London: Routledge, pp.121-150.

Cheng, Y. - Tsang, S. (1995): Agricultural Land Reform in a Mixed System: The Chinese Experience of 1984-1994. China Information, 10(3): 44-74.

Crewett, W. - Korf, B. (2008): Reforming Land Tenure in Ethiopia: Historical Narratives, Political, Ideologies and Multiple Practices. Review of African Political Economy, 35: 203-220.

Deininger, K. (2003): Land Markets in Developing and Transition Economics: Impact of Liberalization and Implications for Future Reform. American Journal of Agricultural Economics, 85(5): $1217-1222$.

Deininger, K. - Jin, S. (2005): The Potential of Land Rental Markets in the Process of Economic Development: Evidence from China. Journal of Development Economics, 78(1): 241-270.

Deininger, K. - Jin, S. (2006): Tenure Security and Land-Related Investment: Evidence from Ethiopia. European Economic Review, 50(5): 1245-1277.

Deininger, K. - Jin, S. (2009): Securing Property Rights in Transition: Lessons from Implementation of China's Rural Land Contracting Law. Journal of Economic Behavior and Organization, 70(1-2): 22-38.

Deininger, K. - Zegara, E. - Lavadenz, I. (2003): Determinants and Impacts of Rural Land Market Activity: Evidence from Nicaragua. World Development, 31(8): 1385-1404.

Del Corral, J. - Perez, J. A. - Roibas, D. (2011): The Impact of Land Fragmentation on Milk Production. Journal of Dairy Science, 94(1): 517-525.

Fan, S. (1991): Effects of Technological Change and Institutional Reform on Production Growth in Chinese Agriculture. American Journal of Agricultural Economics, 7382): 266-275.

Feng, S. (2006): Land Rental Market and Off-Farm Employment-Rural Household in Jiangxi Province, P.R. China. Ph.D. thesis, Wageningen University, The Netherlands.

Feng, S. (2008): Land Rental, Off-Farm Employment and Technical Efficiency of Farm Households in Jiangxi Province, China. NJAS-Wageningen Journal of Life Sciences, 55(4): 363-378.

Feng, S. - Heerink, N. - Ruben, R. - Qu, F. (2010): Land Rental Market, Off-Farm Employment and Agricultural Production in Southeast China: A Plot-Level Case Study. China Economic Review, 21: 598-606.

Gebreselassie, S. (2006): Land, Land Policy and Smallholder Agriculture in Ethiopia: Options and Scenarios. Paper Prepared for the Future Agricultures Consortium Meeting at the Institute of Development Studies, 20-22 March, 2006.

Ghebru, H. - Holden, S. (2008): Factor Market Imperfections and Rural Land Rental Markets in Northern Ethiopian Highlands. In: Holden, S. - Otsuka, K. - Place, F. (eds): The Emergence of Land Markets in Africa: Impacts on Poverty and Efficiency. Resources for the Future, Washington, D.C. pp. 74-92.

He, D. (1995): Changes in the Rural Land Tenure System at the Village Level. Presentation at the symposium on 'Transition of China's Rural Land System: Papers from Symposium on Rural Land Issues in China'. LTC Paper No. 151. Land Tenure Center, University of Wisconsin-Madison, USA.

Ho, P. (2001): Who Owns China's Land? Policies, Property Rights and Deliberate Institutional Ambiguity. The China Quarterly, 166(June): 394-421.

Holden, S. - Deininger, K. - Ghebru, H. (2007): Impact of Land Certification on Land Rental Market Participation in Tigray Region, Northern Ethiopia. MPRA Paper, No. 5211. 
Holden, S. - Deininger, K. - Ghebru, H. (2008): Low-Cost Land Certification and Land Rental Market Participation in Tigray, Ethiopia. Working Paper, Norwegian University of Life Sciences, Aas, Norway.

Holden, S. - Yohannes, H. (2002): Land Redistribution, Tenure Insecurity, and Intensity of Production: A Study of Farm Households in Southern Ethiopia. Land Economics, 78(4): 573-590.

Jin, S. - Deininger, K. (2009): Land Rental Markets in the Process of Rural Structural Transformation: Productivity and Equity Impacts from China. Journal of Comparative Economics, 37(4): 629-646.

Kimura, S. - Otsuka, K. - Sonobe, T. - Rozelle, S. (2011): Efficiency of Land Allocation through Tenancy Markets: Evidence from China. Economic Development and Cultural Change, 59(3): 485-510.

Krusekopf, C. (2002): Diversity in Land-Tenure Arrangements under the Household Responsibility System in China. China Economic Review, 13(2): 297-312.

Kung, J. K. (2002): Off-Farm Labor Markets and the Emergence of Land Rental Markets in Rural China. Journal of Comparative Economics, 30(2): 395-414.

Lang, H. - Ma, X. - Heerink, N. - Shi, X. (2014): Tenure Security and Land Rental Market Development in Rural China-Actual Versus Perceived Security. Presentation at 6th CAER-IFPRI Annual International Conference, Yanglin, Shanxi, China, October 16-17, 2014.

Latruffe, L. - Piet, L. (2012): Does Land Fragmentation Affect Farm Performance? A French Breton Case Study. Proceedings of Conference Eco Prod 2012, Montpellier (France), September, 2012, pp.18-19.

Lin, J. Y. (1992): Rural Reforms and Agricultural Growth in China. The American Economic Review, 82(1): 34-51.

Lin, J. Y. - Yang, D. (2000): Food Availability, Entitlements and the Chinese Famine of 1959-1961. Economic Journal, 110(460): 136-158.

Liu, S. - Carter, M. R. - Yao, Y. (1998): Dimensions and Diversity of Property Rights in Rural China: Dilemmas on the Road to Further Reform. World Development, 26(10): 1789-1806.

Ma, X. (2013): Does Tenure Security Matter? Rural Household Responses to Land Tenure Reform in Northwest China. Ph. D. thesis, Wageningen, The Netherlands: Wageningen University.

Ma, X. - Heerink, N. - Feng, S. - Shi, X. (2015): Farmland Tenure in China: Comparing Legal, Actual and Perceived Security. Land Use Policy, 42(7): 293-306.

Ma, X. - Qiu, T. - Qian, Z. (2015): Land Tenure Security and Farmers' Participation in the Transfer Market. Chinese Rural Economy, 2: 22-37 (in Chinese).

Macours, K. - De Janvry, A. - Sadoulet, E. (2004): Insecurity of Property Rights and Matching in the Tenancy Market. Working Paper, No. 992. Department of Agricultural - Resource Economics, University of California, Berkeley.

Masterson, T. (2007): Land Rental and Sales Market in Paraguay. Working Paper, No. 491. The Levy Economics Institute, Bird College, New York.

Mullan, K. - Grosjean, P. - Kontoleon, A. (2011): Land Tenure Arrangements and Rural - Urban Migration in China. World Development, 39(1): 123-133.

Peters, P. (2004): Inequality and Social Conflict Over Land in Africa. Journal of Agrarian Change, 4(3): 269-314.

Prosterman, R. - Temple, M. - Hanstad, T. (1990): Agrarian Reform and Grassroots Development: Ten Case Studies. A Policy Study of the Curry Foundation, Boulder (CO) and London: Lynne Rienner Publishers.

Putterman, L. (1999): Continuity and Change in China's Rural Development: Collective and Reform Era's in Perspective. New York, NY: Oxford University Press. 
Putterman, L. - Skillman, G. (1993): Collectivization and China's Agricultural Crisis. Journal of Comparative Economics, 17(2): 530-539.

Shipton, P. (2009): Mortgaging the Ancestors: Ideologies of Attachment in Africa. New Haven: Yale University Press.

Sitko, N. - Chamberlin, J. - Hichaambwa, M. (2014): Does Smallholder Land Titling Facilitate Agricultural Growth? An Analysis of the Determinants and Effects of Smallholder Land Titling in Zambia. World Development, 64: 791-802.

Swinnen, J. - Vranken, L. - Stanley, V. (2006): Emerging Challenges of Land Rental Markets: A Review of Available Evidence for the Europe and Central Asia region. Chief Economist's Working Paper Series, 1(4), The World Bank, Washington, D.C.

Tao, R. - Xu, Z. (2007): Urbanization, Rural Land System and Social Security for Migrants in China. Journal of Development Studies, 43(7): 1301-1320.

Teklu, T. - Lemi, A. (2004): Factors Affecting Entry and Intensity in Informal Rental Land Markets in Southern Ethiopian Highlands. Agricultural Economics, 30(2): 117-128.

Tikabo, M. - Holden, S. (2004): Factor Market Imperfections and the Land Rental Market in the Highlands of Eritrea: Theory and Evidence. Paper presented at the CSAE Conference 'Growth, Poverty Reduction and Human Development in Africa'. Available online at http://www.csae. ox.ac.uk/conferences/2004-GPRaHDiA/papers/2a-Tikabo-CSAE2004.pdf.

Vranken, L. - Swinnen, J. (2006): Land Rental Markets in Transition: Theory and Evidence from Hungary. World Development, 34(3): 481-500.

Wang, H. - Riedinger, J. - Jin, S. (2015): Land Documents, Tenure Security and Land Rental Development: Panel Evidence from China. China Economic Review, 36: 220-235.

Yang, D. T. (1997): China's Land Arrangements and Rural Labor Mobility. China Economic Review, 8(2): 101-115.

Yao, S. (1999): A Note on the Causal Factors of China's Famine in 1959-1961. Journal of Political Economy, 107(6): 1365-1369.

Yongyuth, C. - Gershon, F. (1988): The Economic Implications of Land Documents in Rural Thailand. Agricultural Administration and Extension, 29(2): 123-133.

Zhang, W. - Makeham, J. (1992): Recent Developments in the Market for Rural Land Use in China. Land Economics, 68(2): 139-162. 
Founded in 1954

Staff: 100

Research staff: 60

Director: Prof. Károly Fazekas

The Institute of Economics (IE), Centre for Economic and Regional Studies, Hungarian Academy of Sciences is committed to international standards of fundamental and applied research in economics. It has focused increasingly on the analysis of the modern market economy and the transformation of the Hungarian economy. Findings of the research programs of the Institute are made available for and are regularly used by policy making bodies and universities. The Institute of Economics puts emphasis on promoting academic cooperation with other Hungarian and European research centres. It also considers as a priority to develop stronger links with university departments and to take part in the education of the new generation of researchers.

\section{The IE/MTA KRTK current research programme includes:}

Macroeconomics and Growth: Macroeconomic performance and its micro foundations in developed and emerging market economies; growth and disinflation policies, tools and efficacy of monetary and fiscal policy.

Globalisation, EU-integration and Convergence: The research group conducts regular analysis of the characteristic features of the process of globalization and its impact on economic development in Europe and in Hungary.

Public Economics and Public Policies: The role of central and local governments in market economies, intergovernmental fiscal relations, competition and regulatory policies, structural changes in public utilities.

Labour Economics: The transformation of the Hungarian labour market, the economic and institutional aspects of labour market flexibility, the means of employment and wage policies; changes in consumption and income patterns with special attention to age-group related problems.

Agricultural Economics and Rural Development: Agricultural policy modelling, international agricultural trade, EU enlargement issues in agriculture, rural development policy, vertical co-ordination in agriculture, transition of agriculture in CEE countries.

Empirical Industrial Organisation: Causes of changes in corporate governance, corporate finance, firm size (including mergers), boundaries of the firms (innovation, internal production, outsourcing).

Economics of Education: The integration of different directions of research that might make a significant contribution to the reform and modernization of the secondary and higher education in Hungary.

Game Theory: Modelling cooperative games, partition function form games and dynamic cooperative games - besides the theoretical results the aim is also to apply them in economic models.

Economics of Networks: "Traditional" economic issues of network industries such as network externalities and their effects on market processes or the economic issues of network infrastructure. 
Firms, Strategy and Performance: The nature and causes of firm heterogeneity observable within each industry and country, the relationship of this heterogeneity with industry and macro level measures of competitiveness such as productivity, innovation and growth.

Regular Seminars: Economic Theory and Policy Seminar Series.

Regular Publications: Discussion Papers; Budapest Working Papers on the Labour Market (published in cooperation with the Human Resources Department of the Corvinus University of Budapest); IE/CERS/HAS Books; The Hungarian Labour Market - Review and Analysis (one volume per year); Competition and Regulation (one volume per year).

Publications can be downloaded from http://econ.core.hu.

\section{Recent publications in English}

DISCUSSION PAPERS

\begin{tabular}{|c|c|c|}
\hline MTDP 2017/30 & $\begin{array}{l}\text { Sándor JUHÁSZ - } \\
\text { Balázs LENGYEL }\end{array}$ & $\begin{array}{l}\text { Creation and Persistence of Ties in Cluster } \\
\text { Knowledge Networks }\end{array}$ \\
\hline MTDP 2017/29 & $\begin{array}{l}\text { Tamás HAJDU - } \\
\text { Gábor HAJDU }\end{array}$ & $\begin{array}{l}\text { Ambient Temperature and Sexual Activity: } \\
\text { Evidence from Time Use Surveys }\end{array}$ \\
\hline MTDP 2017/28 & $\begin{array}{l}\text { Gergő TÓTH - } \\
\text { Balázs LENGYEL }\end{array}$ & $\begin{array}{l}\text { Inter-Firm Inventor Movements and the } \\
\text { Optimal Structure of Co-Inventor Networks }\end{array}$ \\
\hline MTDP 2017/27 & Péter MIHÁLYI & $\begin{array}{l}\text { Learning, as a Wonder Weapon of Endog- } \\
\text { enous Growth? }\end{array}$ \\
\hline MTDP 2017/26 & $\begin{array}{l}\text { Ágnes CSEH - } \\
\text { Robert W. IRVING - } \\
\text { David F. MANLOVE }\end{array}$ & $\begin{array}{l}\text { The Stable Roommates Problem } \\
\text { with Short Lists }\end{array}$ \\
\hline MTDP 2017/25 & $\begin{array}{l}\text { Ágnes CSEH - } \\
\text { Telikepalli KAVITHA }\end{array}$ & Popular Edges and Dominant Matchings \\
\hline MTDP 2017/24 & $\begin{array}{l}\text { Ashwin ARULSELVAN - } \\
\text { Ágnes CSEH - Martin } \\
\text { GROB - David F. MANLOVE - } \\
\text { Jannik MATUSCHKE }\end{array}$ & $\begin{array}{l}\text { Matchings with Lower Quotas: } \\
\text { Algorithms and Complexity }\end{array}$ \\
\hline MTDP 2017/23 & $\begin{array}{l}\text { Ágnes CSEH - Chien-Chung } \\
\text { HUANG - Telikepalli } \\
\text { KAVITHA }\end{array}$ & $\begin{array}{l}\text { Popular Matchings with Two-Sided } \\
\text { Preferences and One-Sided Ties }\end{array}$ \\
\hline MTDP 2017/22 & András SIMONOVITS & $\begin{array}{l}\text { How did Feldstein (1985) Undervalue the } \\
\text { Optimal Level of Social Security Benefits }\end{array}$ \\
\hline MTDP 2017/19 & $\begin{array}{l}\text { Gábor BÉKÉS - Márta } \\
\text { BISZTRAY }\end{array}$ & $\begin{array}{l}\text { Do Friends Follow Each Other? } \\
\text { FDI Network Effects in Central Europe }\end{array}$ \\
\hline MTDP 2017/16 & $\begin{array}{l}\text { László Á. KÓCZY - } \\
\text { Péter BIRÓ - Balázs SZIKLAI }\end{array}$ & $\begin{array}{l}\text { US vs. European Apportionment Practices: } \\
\text { The Conflict between Monotonicity and } \\
\text { Proportionality }\end{array}$ \\
\hline MTDP 2017/14 & Zsolt DARVAS & $\begin{array}{l}\text { Why Is It So Hard to Reach the EU's } \\
\text { 'Poverty' Target? }\end{array}$ \\
\hline MTDP 2017/13 & $\begin{array}{l}\text { Burak CAN - Péter } \\
\text { CSÓKA - Emre ERGIN }\end{array}$ & $\begin{array}{l}\text { How to Choose a Non-Manipulable } \\
\text { Delegation? }\end{array}$ \\
\hline
\end{tabular}


MTDP 2017/12

MTDP 2017/11

MTDP 2017/10

MTDP 2017/8

MTDP 2017/7

MTDP 2017/6

MTDP 2017/4

MTDP 2017/2

MTDP 2017/1

MTDP 2016/36

MTDP 2016/35

MTDP 2016/33

MTDP 2016/32

MTDP 2016/31

MTDP 2016/30

MTDP 2016/27

MTDP 2016/26

MTDP 2016/25
Dániel BAKSA István KÓNYA

Gábor HAJDU -

Tamás HAJDU

Hubert János KISS -

Ismael RODRIGUEZ-LARA -

Alfonso ROSA-GARCIA

László LŐRINCZ Júlia KOLTAI - Anna Fruzsina GYÖR - Károly TAKÁCS

András SIMONOVITS

Tamás HAJDU -

Gábor HAJDU

Zsombor CSERES-GERGELY

- György MOLNÁR -

Tibor SZABÓ

Gergely VARGA -

János VINCZE

Péter CSÓKA -

P. Jean-Jacques HERINGS

Lajos BARÁTH -

Heinrich HOCKMANN

Zsolt DARVAS

Erik GRANSETH - Wolfgang

KECK - Wolfgang NAGL -

András SIMONOVITS -

Melinda TIR

Kolos Csaba ÁGOSTON Péter BIRÓ - Iain McBRIDE

Tibor CZEGLÉDI - András SIMONOVITS - Endre SZABÓ - Melinda TIR Péter MIHÁLYI Iván SZELÉNYI

Attila LINDNER

- Balázs REIZER

Lajos BARÁTH Imre FERTÖ

Lajos BARÁTH Raushan BOKHUSEVAImre FERTÖ
Interest Premium and Economic Growth:

The Case of CEE

Intra-Couple Income Distribution and

Subjective Well-Being: The Moderating

Effect of Gender Norms

Panic Bank Runs

Collapse of an Online Social Network:

The Blame on Social Capital

Jumping the Welfare Gap in Designing

Public Transfers

Smoking Ban and Health at Birth

Expenditure Responses, Policy

Interventions and Heterogeneous

Welfare Effects in Hungary During

the 2000s

Saver Types: An Evolutionary-Adaptive

Approach

An Axiomatization of the Proportional

Rule in Financial Networks

Technological Differences, Theoretically

Consistent Frontiers and Technical Ef-

ficiency: A Random Parameter Application

in the Hungarian Crop Producing Farms

Some Are More Equal than Others: New

Estimates of Global and Regional Inequality

Negative Correlation between Retirement

Age and Contribution Length?

Integer Programming Methods for Special

College Admissions Problems

Retirement Rules in Hungary: Gainers and Losers

Two Different Sources of Inequalities:

Profits and Rents in Advanced Market

Economies

Frontloading the Unemployment Benefit:

An Empirical Assessment

Productivity and Convergence in European

Agriculture

Studying Farm Insurance Demand

under Financial Constraints 


\begin{tabular}{|c|c|c|}
\hline MTDP 2016/24 & $\begin{array}{l}\text { Imre FERTÖ - } \\
\text { Jeremiás Máté BALOGH }\end{array}$ & $\begin{array}{l}\text { Are the Major European Wine Exporters } \\
\text { Able to Price Discriminate across Their EU } \\
\text { Extra Wine Export Destinations? }\end{array}$ \\
\hline MTDP 2016/23 & Márta BISZTRAY & $\begin{array}{l}\text { The Effect of Foreign-Owned Large Plant } \\
\text { Closures on Nearby Firms }\end{array}$ \\
\hline MTDP 2016/22 & Márta BISZTRAY & $\begin{array}{l}\text { The Effect of FDI on Local Suppliers: } \\
\text { Evidence from Audi in Hungary }\end{array}$ \\
\hline MTDP 2016/20 & $\begin{array}{l}\text { Gábor BÉKÉS - } \\
\text { Áron HORVÁTH - } \\
\text { Zoltán SÁPI }\end{array}$ & $\begin{array}{l}\text { Flood Risk and Housing Prices: } \\
\text { Evidence from Hungary }\end{array}$ \\
\hline MTDP 2016/18 & $\begin{array}{l}\text { Gábor BÉKÉS - } \\
\text { Cecília HORNOK - } \\
\text { Balázs MURAKÖZY }\end{array}$ & $\begin{array}{l}\text { Globalization and the Markups of European } \\
\text { Firms }\end{array}$ \\
\hline MTDP 2016/17 & $\begin{array}{l}\text { Zoltán BAKONYI - } \\
\text { Balázs MURAKÖZY }\end{array}$ & $\begin{array}{l}\text { Centralization of Strategic Decisions during } \\
\text { the Great Recession: An Empirical Analysis } \\
\text { of European Manufacturing Firms }\end{array}$ \\
\hline MTDP 2016/16 & David R. DeREMER & Income Effects and Trade Agreements \\
\hline MTDP 2016/15 & $\begin{array}{l}\text { Stefan DOMONKOS - } \\
\text { András SIMONOVITS }\end{array}$ & $\begin{array}{l}\text { Pensions in Transition in EU11 } \\
\text { Countries between } 1990 \text { and } 2015\end{array}$ \\
\hline MTDP 2016/13 & David R. DeREMER & $\begin{array}{l}\text { The Principle of Reciprocity in the } 21 \mathrm{st} \\
\text { Century }\end{array}$ \\
\hline MTDP 2016/12 & Balázs REIZER & Do Firms Pay Bonuses to Protect Jobs? \\
\hline MTDP 2016/11 & László Á. KÓCZY & $\begin{array}{l}\text { How Brexit Affects European Union Power } \\
\text { Distribution }\end{array}$ \\
\hline MTDP 2016/10 & $\begin{array}{l}\text { Zsolt CSÁFORDI - } \\
\text { László LŐRINCZ - } \\
\text { Balázs LENGYEL- } \\
\text { Károly Miklós KISS }\end{array}$ & $\begin{array}{l}\text { Productivity Spillovers through Labor } \\
\text { Flows: The Effect of Productivity Gap, } \\
\text { Foreign-Owned Firms and Skill-Relatedness }\end{array}$ \\
\hline MTDP 2016/9 & $\begin{array}{l}\text { Dávid CSERCSIK - } \\
\text { Hubert János KISS }\end{array}$ & $\begin{array}{l}\text { Optimal Payments to Connected Depositors } \\
\text { in Turbulent Times - a Markov Chain } \\
\text { Approach }\end{array}$ \\
\hline MTDP 2016/6 & $\begin{array}{l}\text { Balázs KIRÁLY - } \\
\text { András SIMONOVITS }\end{array}$ & $\begin{array}{l}\text { Saving and Taxation in a Voluntary } \\
\text { Pension System: Toward an Agent-Based } \\
\text { Model }\end{array}$ \\
\hline MTDP 2016/4 & Mária CSANÁDI & $\begin{array}{l}\text { China in between Varieties of Capitalism } \\
\text { and Communism }\end{array}$ \\
\hline MTDP 2016/3 & $\begin{array}{l}\text { Péter CSÓKA - } \\
\text { P. Jean-Jacques HERINGS }\end{array}$ & $\begin{array}{l}\text { Decentralized Clearing in Financial } \\
\text { Networks }\end{array}$ \\
\hline MTDP 2016/2 & István KÓNYA & Labor Flows in Hungary and Europe \\
\hline MTDP 2016/1 & $\begin{array}{l}\text { Attila HAVAS - K. Matthias } \\
\text { WEBER }\end{array}$ & $\begin{array}{l}\text { The 'Fit' between Forward-Looking } \\
\text { Activities and the Innovation Policy Gov- } \\
\text { ernance Sub-System. A Framework } \\
\text { to Explore Potential Impacts }\end{array}$ \\
\hline MTDP 2015/57 & $\begin{array}{l}\text { Zsolt DARVAS - } \\
\text { András SIMON }\end{array}$ & $\begin{array}{l}\text { Filling the Gap: Open Economy } \\
\text { Considerations for More Reliable Potential } \\
\text { Output Estimates }\end{array}$ \\
\hline
\end{tabular}


MTDP 2015/55

MTDP 2015/54

MTDP 2015/53

MTDP 2015/52

MTDP 2015/51

MTDP 2015/50

MTDP 2015/49

MTDP 2015/48

MTDP 2015/45

MTDP 2015/44

MTDP 2015/42

MTDP 2015/41

MTDP 2015/40

MTDP 2015/39

MTDP 2015/37

MTDP 2015/35
Tamás HAJDU -

Gábor HAJDU

Attila HAVAS

Markus KINATEDER - Hubert Would Depositors Like to Show Others

János KISS - Ágnes PINTÉR that They do not Withdraw? Theory

Erel SEGAL-HALEVI -

Balázs SZIKLAI

Zsófia BENEDEK -

Bálint BALÁZS

Balázs LENGYEL -

Rikard ERIKSSON

Balázs SZIKLAI

Károly Attila SOÓS

Péter BÍRÓ - Walter KERN -

Daniël PAULUSMA -

Péter WOJUTECZKY

Gábor OBLATH -

Éva PALÓCZ -

Dávid POPPER -

Ákos VALENTINYI

\section{Zsolt DARVAS}

Gergely CSORBA Zoltán PÁPAI

Dániel HAVRAN -

Kata VÁRADI

Judit KARSAI

András SIMONOVITS

Mária LACKÓ and Experiment

The Association between Experiential and Material Expenditures and Subjective Well-Being: New Evidence from Hungarian Survey Data

Various Approaches to Measuring Business Innovation: Their Relevance for Capturing Social Innovation

Resource-Monotonicity and Population-Monotonicity in Cake-Cutting Efficient Support of Short Food Supply Chains in Hungary: A Spatial Analysis Co-Worker Networks, Labour Mobility, and Productivity Growth in Regions On How to Identify Experts in a Community

Geographical and Sectorial Concentration in Czech, Hungarian and Slovak Exports

The Stable Fixtures Problem with Payments

Economic Convergence and Structural Change in the New Member States of the European Union Convergence in Volumes, Prices and the Share of Services, with Implications for Wage Convergence: An Expenditure-Side Analysis

The Grand Divergence: Global and European Current Account Surpluses Does One More or One Less Mobile Operator Affect Prices? A Comprehensive Ex-post Evaluation of Entries and Mergers in European Mobile Telecommunication Markets

Price Impact and the Recovery of the Limit Order Book: Why should We Care about Informed Liquidity Providers? Are CEE States Successful as Venture Capitalists?

Socially Optimal Child-Related Transfers and Personal Income Tax with Endogenous Fertility

Some Explanation of Disparities of Mortality Rates of Working Age Population in Eastern, Central and Western Europe 


$\begin{array}{ll}\text { MTDP 2015/34 } & \begin{array}{l}\text { Balázs MURAKÖZY - } \\ \text { Katheryn NILES RUSS } \\ \text { David R. DeREMER }\end{array} \\ \text { MTDP 2015/33 } & \text { Balázs MURAKÖZY } \\ \text { MTDP 2015/32 } & \begin{array}{l}\text { Balázs MURAKÖZY - } \\ \text { Álmos TELEGDY }\end{array} \\ \text { MTDP 2015/30 } & \begin{array}{l}\text { Cecília HORNOK - } \\ \text { Balázs MURAKÖZY } \\ \text { Gábor BÉKÉS }\end{array} \\ \text { MTDP 2015/29 } & \end{array}$

MTDP 2015/28 Dzsamila VONNÁK

MTDP 2015/27 Gábor BÉKÉS -

MTDP 2015/26 Gábor BÉKÉS -

Péter HARASZTOSI

MTDP 2015/25 Gábor BÉKÉS - Gianmarco

I.P. OTTAVIANO

MTDP 2015/24 András SIMONOVITS

MTDP 2015/23

MTDP 2015/21

MTDP 2015/19

MTDP 2015/18

MTDP 2015/17

MTDP 2015/16

Paola CONCONI - David R.

DeREMER - Georg

KIRCHSTEIGER - Lorenzo

TRIMARCHI - Maurizio

ZANARDI

László GULYÁS - Tamás

- Márton VARGA
Competition with Multinational Firms:

Theory and Evidence

Opportunities for Cooperation in Removing

Prohibitive Trade Barriers

How do Exporters React to the Prices of

Their Competitors?

Political Incentives and State Subsidy

Allocation: Evidence from Hungarian

Municipalities

Markup and Productivity of Exporters

and Importers

Measuring Regional Competitiveness:

A Survey of Approaches, Measurement and Data

Decomposing the Riskiness of Corporate

Foreign Currency Lending: The Case of

Hungary

The Ladder of Foreign Sales Inter-

nationalization Modes of European Firms

Grid and Shake - Spatial Aggregation and

Robustness of Regionally Estimated

Elasticities

Micro-Founded Measurement of Regional

Competitiveness in Europe

Optimal Child-Related Transfers and

Personal Income Tax with Endogenous

Fertility

MÁHR - István János TÓTH

Factors to Curb Tax Evasion: Evidence

from the TAXSIM Agent-Based Simulation

Model

Éva FODOR - Dániel HORN “Economic Development” and Gender Equality: Explaining Variations in the

Gender Poverty Gap after Socialism

Péter ELEK - Balázs VÁRADI Effects of Geographical Accessibility

on the Use of Outpatient Care Services:

Quasi-Experimental Evidence from Panel

Count Data

The Persistent High-Tech Myth in the EC

Policy Circles. Implications for the EU10

Countries

How does Labour Market Structure Affect the Response of Economies to Shocks?
István KÓNYA-

Stephen MILLARD 


\begin{tabular}{|c|c|c|}
\hline MTDP 2015/15 & László LÖRINCZ & $\begin{array}{l}\text { Inter-Ethnic Dating Preferences of Roma } \\
\text { and non-Roma Secondary School Students }\end{array}$ \\
\hline MTDP 2015/14 & András SIMONOVITS & $\begin{array}{l}\text { Optimal Child-Related Transfers with } \\
\text { Endogenous Fertility }\end{array}$ \\
\hline MTDP 2015/13 & $\begin{array}{l}\text { Júlia KIRÁLY - } \\
\text { András SIMONOVITS }\end{array}$ & $\begin{array}{l}\text { Mortgages Denominated in Domestic } \\
\text { and Foreign Currencies: Simple Models }\end{array}$ \\
\hline MTDP 2015/12 & $\begin{array}{l}\text { Tamás SOLYMOSI - } \\
\text { Balázs SZIKLAI }\end{array}$ & $\begin{array}{l}\text { Universal Characterization Sets } \\
\text { for the Nucleolus in Balanced Games }\end{array}$ \\
\hline MTDP 2015/11 & Dávid CSERCSIK & $\begin{array}{l}\text { Lying Generators: Manipulability of } \\
\text { Centralized Payoff Mechanisms } \\
\text { in Electrical Energy Trade }\end{array}$ \\
\hline MTDP 2015/9 & Péter CSÓKA & Fair Risk Allocation in Illiquid Markets \\
\hline MTDP $2015 / 5$ & $\begin{array}{l}\text { Péter BENCZÚR - } \\
\text { István KÓNYA }\end{array}$ & $\begin{array}{l}\text { Interest Premium, Sudden Stop, and } \\
\text { Adjustment in a Small Open Economy }\end{array}$ \\
\hline MTDP 2015/4 & $\begin{array}{l}\text { Gergely VARGA - } \\
\text { János VINCZE }\end{array}$ & $\begin{array}{l}\text { Ants and Crickets: Arbitrary Saving Rates } \\
\text { in an Agent-Based Model with Infinitely } \\
\text { Lived-Agents }\end{array}$ \\
\hline MTDP 2015/2 & $\begin{array}{l}\text { Edina BERLINGER - } \\
\text { György WALTER }\end{array}$ & $\begin{array}{l}\text { Introduction of an Income Contingent } \\
\text { Repayment Scheme for non-Performing } \\
\text { Mortgage Loans. Lessons from Hungary's } \\
\text { Case }\end{array}$ \\
\hline
\end{tabular}

BUDAPEST WORKING PAPERS ON THE LABOUR MARKET

\begin{tabular}{|c|c|c|}
\hline BWP 2017/8 & $\begin{array}{l}\text { Dániel HORN - } \\
\text { Hubert János KISS }\end{array}$ & $\begin{array}{l}\text { Which Preferences Associate with School } \\
\text { Performance? - Lessons from a University } \\
\text { Classroom Experiment }\end{array}$ \\
\hline BWP 2017/7 & $\begin{array}{l}\text { Joris GHYSELS - } \\
\text { Zoltán HERMANN - } \\
\text { Iryna RUD - Melline SOMERS }\end{array}$ & $\begin{array}{l}\text { The Effect of Increased General Education } \\
\text { in Vocational Schools - Evidence from a } \\
\text { Hungarian Vocational School Reform }\end{array}$ \\
\hline BWP 2017/6 & Sofie CABUS - Eszter NAGY & $\begin{array}{l}\text { Performance of Hungarian Firms: Are Ap- } \\
\text { prentices an Asset or a Liability? } \\
\text { Evidence from a Unique Matched Employ- } \\
\text { er - Employee Dataset }\end{array}$ \\
\hline BWP 2017/5 & $\begin{array}{l}\text { Anna LOVÁSZ - } \\
\text { Ewa CUKROWSKA- } \\
\text { TORZEWSKA - } \\
\text { Mariann RIGÓ - } \\
\text { Ágnes SZABÓ-MORVAI - } \\
\text { Andrea KISS }\end{array}$ & $\begin{array}{l}\text { One Size Fits All? Gender Differences in } \\
\text { the Effect of Subjective Feedback }\end{array}$ \\
\hline BWP 2017/4 & $\begin{array}{l}\text { Fritz SCHILTZ - } \\
\text { Chiara MASCI - } \\
\text { Tommaso AGASISTI - } \\
\text { Dániel HORN }\end{array}$ & $\begin{array}{l}\text { Using Machine Learning to Model } \\
\text { Interaction Effects in Education: } \\
\text { A Graphical Approach }\end{array}$ \\
\hline BWP 2017/3 & $\begin{array}{l}\text { Ágnes SZABÓ-MORVAI - } \\
\text { Anna LOVÁSZ }\end{array}$ & $\begin{array}{l}\text { Childcare and Maternal Labor Supply - } \\
\text { A Cross-Country Analysis of Quasi-Experi- } \\
\text { mental Estimates from } 7 \text { Countries }\end{array}$ \\
\hline
\end{tabular}




\begin{tabular}{|c|c|c|}
\hline BWP 2017/2 & $\begin{array}{l}\text { Alfa DIALLO - } \\
\text { Zoltán HERMANN }\end{array}$ & $\begin{array}{l}\text { Does Teacher Gender Matter in Europe? } \\
\text { Evidence from TIMSS Data }\end{array}$ \\
\hline BWP 2017/1 & Júlia VARGA & $\begin{array}{l}\text { The Effects of Policies Concerning } \\
\text { Teachers' Wages on Students' Performance }\end{array}$ \\
\hline BWP 2016/5 & Péter ELEK - János KÖLLÖ & $\begin{array}{l}\text { Eliciting Permanent and Transitory Unde- } \\
\text { claredWorkfromMatchedAdministrativeandSurveyData }\end{array}$ \\
\hline BWP 2016/4 & Júlia VARGA & $\begin{array}{l}\text { Out-Migration and Attrition of Physicians } \\
\text { and Dentists before and after EU Accession } \\
\text { (2003 and 2013). The Case of Hungary }\end{array}$ \\
\hline BWP 2016/2 & $\begin{array}{l}\text { Luca Flóra DRUCKER - } \\
\text { Dániel HORN }\end{array}$ & $\begin{array}{l}\text { Decreased Tracking, Increased Earning: } \\
\text { Evidence from the Comprehensive Polish } \\
\text { Educational Reform of } 1999\end{array}$ \\
\hline BWP 2016/1 & $\begin{array}{l}\text { Ewa CUKROWSKA- } \\
\text { TORZEWSKA }\end{array}$ & $\begin{array}{l}\text { Comparative Analysis of the Motherhood } \\
\text { Gap in Employment and Wages: The Role } \\
\text { of Family Policies and Their Interaction }\end{array}$ \\
\hline BWP 2015/7 & $\begin{array}{l}\text { Tamás HAJDU - } \\
\text { Gábor KERTESI - } \\
\text { Gábor KÉZDI }\end{array}$ & $\begin{array}{l}\text { High-Achieving Minority Students } \\
\text { can Have More Friends and Fewer } \\
\text { Adversaries. Evidence from Hungary }\end{array}$ \\
\hline BWP 2015/5 & Tamás KELLER & $\begin{array}{l}\text { Sticky Assessments - The Impact of } \\
\text { Teachers' Grading Standard on Pupils' } \\
\text { School Performance }\end{array}$ \\
\hline BWP 2015/4 & Tamás KELLER & $\begin{array}{l}\text { The Power of Family? The Change in Aca- } \\
\text { demic Achievement after Breakdown of the } \\
\text { Biological Family }\end{array}$ \\
\hline BWP 2015/3 & $\begin{array}{l}\text { Zsombor CSERES-GERGELY } \\
\text { - Ágota SCHARLE - } \\
\text { Árpád FÖLDESSY }\end{array}$ & $\begin{array}{l}\text { Evaluating the Impact of a Well-Targeted } \\
\text { Wage Subsidy Using Administrative Data }\end{array}$ \\
\hline
\end{tabular}

\section{LABOUR MARKET YEARBOOKS}

The Hungarian Labour Market, 2016

The Hungarian Labour Market, 2015 - Review and Analysis

The Hungarian Labour Market, 2014 - In Focus:

Labour Market of the Public Sector

The Hungarian Labour Market, 2013 - Review and Analysis
Eds: Zsuzsa BLASKÓ -

Károly FAZEKAS

Eds: Károly FAZEKAS Júlia VARGA

Eds: Károly FAZEKAS László NEUMANN

Eds: Károly FAZEKAS Péter BENCZÚR Álmos TELEGDY 


\section{INSTRUCTIONS FOR AUTHORS}

Acta Oeconomica publishes original research papers, review articles, book reviews and announcements in the field of economics. Papers are accepted on the understanding that they have not been published or submitted for publication elsewhere in English language and that they are subject to peer review. Papers accepted for publication by the editorial board are subject to editorial revision.

\section{Submission of manuscripts}

Acta Oeconomica insists on electronic submission of manuscripts. Manuscripts should be sent as attachment by e-mail in MS Word (.doc or .docx) file to judit.vanyai@krtk.mta.hu with operating system MS Windows $95 / 98$ or later versions.

\section{Presentation of manuscripts}

Manuscripts should be written in clear, concise, and grammatically correct English. The order should be as follows: title page, abstract, keywords, Journal of Economic Literature classification numbers, text, references, tables, figure captions, appendix.

Title page. The title should be concise and informative. A short running title of no more than 40 characters should also be supplied. This is followed by the first name(s) and surname of the author(s), and the name of the institution the author works at. The mailing address and e-mail address of the corresponding author must also be given in a footnote.

Abstract should not exceed 200 words.

Keywords and literature classification index should not exceed 10 items.

Acknowledgements should be placed on the first page.

References in the text should follow the author-date format without comma. Where there are more than two authors, the name of the first author should be used, followed by et al. Publications by the same author(s) in the same year should be listed as e.g. (1999a), (1999b). List the references in chronological order in the text and in alphabetical order at the end of the paper. The style and punctuation of references should conform to that used in the journal. See the following examples:

- Hámori, J. R. - Kovács, B. J. - Szabó, G. (1998): Felzárkózás és előretörés (Catching up and Go ahead). Közgazdasági Szemle, 13(10): 45-53.

- Smith, B. G. (1998): Financial Problems and their Solutions in the Transition Countries. In: Gordon, M. - Ratherford, R. K. (eds): Approaching to the EU. London: Macmillan, pp. 234-245.

- Zacher, M. (1996): Evolution and Revolution in Industrial Economics.2. $2^{\text {nd }}$ ed., Budapest: Közgazdasági Könyvkiadó.

Tables. Each, bearing a title, should be self-explanatory. They should be mentioned in the text, numbered consecutively with Arabic numerals and placed on separate sheets at the end of the manuscript, following the References. Their approximate position should be indicated in the manuscript. Figures should be submitted electronically in TIFF or JPG file format (min. 300 dpi). Excel files with edited diagrams and charts are also accepted. Please apply only black and white colours. In the legend use different signs, not colours. All figures should be numbered consecutively with Arabic numerals and the approximate position should be indicated in the text.

Permissions. It is the responsibility of the author to obtain written permission for quotations, and for the reprinting of illustrations or tables. 
CVs of the authors should not exceed 200 words. The style should conform to that used in the journal.

Advertisements may be inserted by the Publisher.

Proofs and reprints. Proofs will be sent to the corresponding author electronically in pdf format, who is requested to return it to the Editor within 5 days of receipt. Ten reprints of each paper are supplied free of charge to the corresponding author. Additional reprints can be ordered on a Reprint Order.

A copy of the Copyright Transfer Statement will be sent to the authors of the papers accepted for publication. Manuscripts will be processed only after receiving the signed copy of the statement.

Open Access. Authors can use the Optional Open Access publication model for a specific publishing fee. It is an option for the author to pay the Article Processing Charge (APC) and have the final full text version of his/her article published as an Open Access one. The full text of an Open Access paper is freely accessible through the official website of the journal. The peer review process and the quality requirements, as well as the publishing process are the same in case of both traditional and Open Access manuscripts. Both accepted new manuscripts and papers published earlier can be Open Access. The APC of an Open Access article is 590 EUR (770 USD) + VAT, where applicable, but it can be even less. Akadémiai Kiadó offers discounts for Hungarian authors, institutions of low-and middle-income countries and Editorial Board members. Discounts may not be combined. The above fee does not include any normal (excess) page fees and colour charges. By signing the Open Access License Agreement and paying the APC, the Author retains the ownership and further rights related to the Article while ensuring the wide accessibility of the Article in the written and electronic media controlled by Akadémiai Kiadó. See www.oopenart.com for details. Should you have any questions, please contact the editors of the journal. 


\section{REFEREEING PROCEDURE}

The complete refereeing process for the journal is double-blind. The author(s) and the referees then cannot have any knowledge of each other at any time.

Each paper is refereed by (at least) two referees.

The assignment of three (two active and one on reserve) referees is made by the Editorial Board. To be able to do so each member of the Board receives an anonymous, maximum one page long abstract of the paper(s).

The decision after the first round of refereeing can be:

1. accept the paper without further corrections,

2. accept the paper with corrections and changes suggested by the referees and the editor(s),

3. request major changes and the paper is returned to the referees for a second round of refereeing,

4. the paper should be completely re-written along some well-specified guidelines and the journal would then accept a re-submission (the paper would be considered a new submission) and

5. outright rejection.

In order to increase the effectiveness of the review process, authors are kindly asked to respond to the comments and suggestions of the referees.

The Editorial Board based on the referee's report makes the final acceptance or rejection decision. The Editor-in-Chief ensures the absolute confidentiality of the whole process. 
